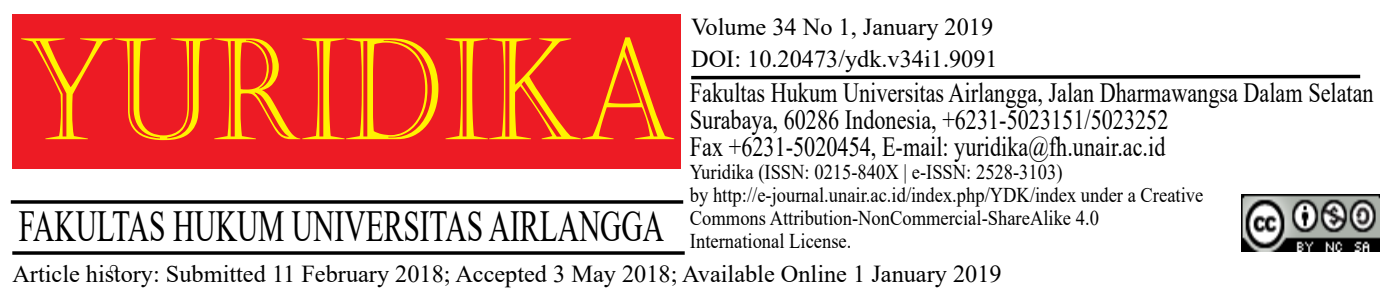

\title{
Understanding the Plurality of Consumer Dispute Resolution in Indonesia: a Comparative Study with Singapore
}

\author{
Anita Afriana and Efa Laela Fakhriah \\ anita.afriana@unpad.ac.id \\ University of Padjadjaran
}

\begin{abstract}
Globalization has impacted many aspects of human life. It accelerates trade transactions between producers and consumers. Despite of numerous advantageous it brings, globalization also has a potential to cause various disadvantageous and loss to the consumers that ultimately lead to consumer disputes. In general, consumer disputes involve small amount of loss and complaint filed by the consumers for material compensation. In Indonesia, consumer dispute resolution is carried out not only by the Consumer Dispute Settlement Body (BPSK) but also through the courts. Recently, there are many newly-established consumer dispute settlement institutions. This article is part of a completed study discussing a plurality of consumer dispute settlement in Indonesia and a comparative analysis with the one available in Singapore. The study applies normative juridical research method and qualitative juridical analysis, it can be concluded that the plurality of consumer dispute settlement in Indonesia has led to convoluted mechanisms and procedures in settling disputes. This leads to a lack of legal certainty. The comparative law study being the instrument of this study is a critical instrument in the framework of legal reformation. Result shows that in Singapore, consumer disputes are resolved by a Small Claims Procedure method on State Court and through CASE as a private nonlitigation agency with specific consumer characteristics and disputes.
\end{abstract}

Keywords: Comparative Law; Plurality; Consumer Dispute. 


\section{Introduction}

Legal entities and human beings are legal subjects. It has become a nature of a human as a social being to require social interaction with one another. Different objectives in social interaction may cause conflicts of interest. Conflicts that cannot be resolved will develop into disputes. Disputes can be settled through dispute settlement mechanism. With the increasingly widespread business transaction activities, disputes between parties involved is inevitable. Each dispute that occurs always demands a quick solution and resolution. The more and the wider the trading activities, the higher the frequency of disputes. This means that it is very likely that more disputes must be resolved. From the point of view of the process (mechanism), business disputes settlement can be carried out conventionally, which is resolved through a court (litigation) using a legal approach. The alternative mechanisms are through peaceful agreement or negotiation. This alternative dispute resolution mechanism (non-litigation) does not apply a formal legal approach.

Based on the Indonesian justice system, it is the authority of a judge to examine and decide cases. The duty of the judge (court) is to receive, examine, and decide on any civil or criminal cases filed to the court. From the perspective of a decision-maker, a decision can be made from an adjudicative manner, namely, a settlement mechanism that is characterized by decision-making authority carried out by third parties to settle disputes between parties who consent or compromise through quasi-adjudicative, which is a combination of consensual and adjudicative elements. The principle difference between settlement through court and outside the court is concerning whether or not legal certainty can be achieved, which is one of the objectives of the law through court decisions, other than justice and expediency.

Over the course of time and the needs of the community, the settlement of civil disputes outside the court increases. Various fields have their own settlement institutions outside the court that are regulated by legislation. One example of civil disputes is consumer disputes. Consumer disputes may easily occur considering that humans in their daily activities always consume goods and/or services both on a big and small scale. 
The definition of consumer disputes is not explained in Law No. 8 of 1999 on Consumer Protection, but it is found in the Decree of the Minister of Industry and Trade No. 350/MPP/Kep/12/2001 on Implementation of Duties and Authorities of the Consumer Dispute Settlement Body, which states that consumer disputes claiming compensation for damage, pollution and/or suffering losses due to consumption of goods and/or utilizing services. Az. Nasution ${ }^{1}$ argued that consumer disputes are disputes between consumers and undertaking (public or private) about consumer products: certain goods and/or services. To determine whether a dispute is considered a consumer dispute or not, it should be noted whether the consumer in dispute is a consumer as intended by the consumer in Law No. 8 of 1999 on Consumer Protection (herein after referred to as "UUPK") and the disputed product is as a consumer product. Based on UUPK, consumer dispute resolution can be conducted peacefully, through the court or the Consumer Dispute Settlement Body (BPSK).

Statistically speaking, it is relatively rare for consumer disputes to be resolved through the court. ${ }^{2}$ The reason is that consumer disputes are worth a relatively small loss, inexpensive, and simple disputes. If resolved through the court through the proceedings stages starting from filing a lawsuit until the decision, it is considered ineffective in terms of time and costs incurred. In its development, there are many alternative dispute resolution institutions outside the court in addition to BPSK. According to the Regulation of The Indonesian Financial Service Authority (Otoritas Jasa Keuangan “OJK”) (POJK) No. 1/POJK.07/2014 on Alternative Dispute Settlement Institution (Lembaga Alternatif Penyelesaian Sengketa "LAPS") in Financial Service Sector, there are several consumer settlement institutions, among others in the field of banking (LAPSPI), capital markets, and commodity futures. The background to the establishment of the LAPS in the OJK is to provide dispute settlement institutions for consumers with mechanism that can be undertaken

\footnotetext{
1 Az. Nasution, Consumer Protection Law, An Introduction, (Diadit Media 2011).[229].

2 Anita Afriana, 'Business Dispute Settlement through Court with A Prompt Mechanism and Legal Certainty (Small Claims Court) In the Framework of Reforming the National Civil Procedure Law' (Padjadjaran University 2017).
} 
outside the court. Therefore, it can be concluded that the current field of consumer dispute resolution is still pluralistic.

The aforementioned facts indicate that public trust in the court as an institution for resolving disputes fades, hence, they opt the existence of alternative dispute resolution institution. Actually, dispute resolution through the court provides more legal certainty because the decision that has an executorial title can be imposed if the decision has a permanent legal effect. Legal certainty can be interpreted that someone will be able to get something that he/she expects under certain circumstances. Legal certainty can be interpreted as the clarity of the norm so that it can be used as a guideline. ${ }^{3}$ This is different from resolving disputes from outside the court, where one party can file an appeal to the court. Thus, the decisions do not have an enforcement power so that it truly depends on the goodwill of the parties. The decision from dispute settlement institutions that are outside the court cannot be enforced to the parties so that it does not provide legal certainty to the wining party. Thus, it can be said that there is a lack of simplicity of procedures in resolving consumer disputes in Indonesia since the parties can still file an appeal to the district court upon decisions made through non-litigation processes.

In the subsequent part, this paper will discuss the pluralistic existence of institutions for consumer dispute resolution in Indonesia and the comparison with Consumer dispute resolution in Singapore. The decision to choose Singapore as a comparative country is based on the reason that Singapore and Indonesia are both countries in Southeast Asia, although Singapore is based on the common law system tradition. This article compares consumer dispute settlement mechanism in Singapore, including the fact that Singapore has implemented Small Claims Court to settle consumer dispute settlement in court. The dispute resolution in this developed country is conducted effectively.

\footnotetext{
3 Tata Wijayanta, 'Principle of Legal Certainty, Justice and Benefit in Relation to Commercial Court Decision of Bankruptcy’ (2014) 4 Dinamika Hukum.[219].
} 


\section{Plurality in Consumer Dispute Resolution in Indonesia}

In the global era, the world seems to be borderless. People can start their business and work anywhere without any obstacles as long as they are able to face their opponents competitively. The world economy is characterized by free trade. ${ }^{4}$ One of the implications of such situation that is often occurred is the emergence of disputes or conflicts. Disputes are things that have become a part of human life, thus, they are inseparable from human life.

One type of dispute that is often encountered on a day-to-day basis is a business disputes that involve consumers. Consumer disputes are usually on matters concerning relatively small loses or small claims. The method that can be taken is to resolve the dispute with a dispute resolution mechanism conventionally through the court, or non-litigation dispute resolution mechanisms. Dispute resolution outside the judiciary system is often referred to as the Alternative Dispute Resolution (ADR). ${ }^{5}$

A method that can be used in the alternative dispute resolution is negotiation, mediation, consolidation and arbitration. However, a mechanism that is commonly resorted is the settlement of disputes through a negotiation and mediation as an alternative dispute resolution mechanism. By comparison, mediation in court should be able to accelerate the resolution of civil disputes through mediation (peace) without having to proceed to the settlement through a civil justice mechanism, but the fact is that the mediation process often fails to reconcile the parties. ${ }^{6}$ Arbitration is the most similar method to a court settlement, but with the specificity to resolve disputes in the field of trade and the rights are fully controlled by the parties, by issuing a quick and fair decision, without any complicated formality or procedure that can hinder dispute.

In principle, of resolving civil disputes is carried out peacefully, this is because

\footnotetext{
${ }^{4}$ Ngadino, 'The Role of Law in Economic Globalization' (2014) 1 Jurnal Pembaharuan Hukum.[60].

5 Susanti Adi Nugroho, Mediation as an Alterantif Dispute Resolution (Telaga Ilmu Indonesia 2009).[12].

${ }^{6}$ Candra Irawan, 'Problems of the Implementation of the Decree of the Supreme Court of the Republic of Indonesia No. 1 of 2008 in Civil Dispute Settlement in Indonesia' (2015) 1 Jurnal Hukum Acara Perdata ADHAPER.[62].
} 
whether or not the dispute arises entirely depends on the disputing parties, and it is also on their decision whether they will continue dispute or make peace. Therefore, even though the dispute has been submitted to the court to be resolved by litigation, the efforts to resolve the dispute peacefully must still be pursued. In practice, settlements through non-court institutions often do not achieve an effective and efficient dispute resolution because even if there is a clear regulation of absolute competence between the court and arbitration, the disputing parties often still filed their dispute to the court to examine and decide the case, therefore the settlement of the dispute is no longer effective and efficient. Indonesian justice system requires prompt settlement of civil disputes in the District Court given a large number of populations so that the tendency of disputes is also high. Considering that the mediation settlement does not work optimally, it even caused the process of proceeding to be longer, ${ }^{7}$ therefore, the development of legal relations in the economic and other civil fields in the community required a simpler and faster dispute settlement procedure, thus, the costs are efficient, especially in a simple legal relationship.

Consumer dispute resolution through the courts will be in the realm of civil disputes carried out in stages, namely through the judiciary in the general court environment. The settlement of consumer disputes outside the court as well as the settlement of consumer disputes in court is carried out based on the voluntary choice of the disputing parties. The UUPK does not further explain the intention regarding 'the voluntary choice' of the parties to determine the resolution of consumer disputes. The voluntary choice of the parties indicates that the settlement of disputes that occur between consumers and undertaking is basically a compromise of the disputing parties. However, if there is no agreement between the consumer and undertaking regarding the choice of forum, then consumers have the freedom to make choices whether to file a lawsuit to the court or other ADR institution. For parties who have chosen a consumer dispute settlement through court, consumers cannot file a lawsuit against undertaking

${ }^{7}$ R. Benny Riyanto, 'Remodelling and Repositioning of Court's Mediation in Indonesia' (2016) 1 Diponegoro Law Review.[28]. 
through the court simultaneously. The lawsuit can only be done through a court if the settlement of a consumer dispute outside the court that has been taken is declared unsuccessful by one of the parties to the dispute.

As a matter of fact, a dispute involving a relatively small claims can be solved by small claims court whose settlement time is limited to 25 days. By accelerating the way to resolve disputes, it will benefit all levels of society to access justice in a simple, low-cost, and in a timely manner, ${ }^{8}$ but in a dispute involving a big loss that exceeds 200 million Rupiah, it must go through stages of civil dispute resolution in general. In Indonesia, the existence of Small Claims Court is regulated under the Regulation of the Supreme Court (PerMA) No 2 of 2015 with single judge and there is no opportunity to make apeal to the higher court. One of the weaknesses of the Small Claims Court in Indonesia is that the plaintiff and defendant must be in the same district court jurisdiction.

Alternative dispute resolution mechanism that are non-litigation through negotiation, mediation, conciliation, and arbitration are preferred by consumers because they are perceived to be simpler and faster so that it is more efficient in terms of financial costs. In addition, the result is an agreement that does not place the parties' positions as losers and winners, but all parties wishes will be accommodated (win-win solution). The discussion section will explain non-litigation consumer dispute settlement institutions in Indonesia that are limited only to BPSK, LAPSPI and BAPTI institutions.

\section{Consumer Dispute Settlement Body (Badan Penyelesaian Sengketa Konsumen “BPSK")}

Consumer dispute resolution through BPSK is not mentioned directly in the UUPK. The UUPK only mentions that consumers can sue business actors through institutions that have a function of resolving disputes between consumers and business actors. However, this unclarity is answered based on the provisions of

${ }^{8}$ Anita Afriana dan Isis Ikhwansayah, 'Questioning The Small Claims Court in Indonesia In The Framework of National Civil Procedural Law Reform' (2016) 16 Jurnal Dinamaika Hukum.[269]. 
Article 52 Letter a of the UUPK, that the institution in question is BPSK. The lawsuit filed by consumers to businesses through BPSK is a form of consumer dispute resolution outside the court. Philosophically it is intended to handle and resolve disputes between consumers and business actors, which initially BPSK resolves consumer disputes that are small and simple, meaning that the government forms BPSK in the context of fair equity. This is because consumer disputes are generally small, so if submitted to the District Court, the court costs and compensation that consumers will receive is unbalanced. Therefore, BPSK resolves consumer disputes promptly, meaning that within 21 days the dispute must be decided; BPSK resolves consumer disputes in a simple way, meaning that the administrative process and the decision-making process is relatively simple and can be carried out by the parties; and BPSK resolves consumer disputes efficiently, meaning that the trial fees that are charged to consumers are very light and affordable. The principle of dispute resolution that is prompt, simple, and costefficient has generally been implemented in some BPSK where consumer dispute trials are free of charge and settled in a timely manner.

The formation of BPSK is also intended to help to reduce the workload of District Courts. Therefore, BPSK are limited in big city and only handles civil cases that generally claim compensation for losses suffered directly by consumers for errors and/or negligence of the business actor. In resolving consumer disputes, BPSK acts only to determine the form and amount of compensation as well as determine certain actions to ensure that there will be no repeat of losses suffered by consumers. BPSK is only authorized to impose compensation from undertaking to consumers materially, not immaterial compensation. However, in several occasions, in practice, BPSK decisions are beyond their authority such as cancelling an agreement, to take a case in point, the BPSK Decision No 1230/Arbitrase/BPSK$\mathrm{BB} / \mathrm{V} / 2016$ that was objected and filed to the District Court so that it was later 
settled by decision No 198/PDT-SUS/BPSK/2016/PN. RAP. ${ }^{9}$

Types of dispute settlement trial that can be conducted by BPSK are the trial by means of conciliation, mediation, and arbitration. All types of consumer settlement trials are based on the agreement of the parties (consumers and businesses) voluntarily without coercion. The results of consumer dispute settlement through BPSK can basically be divided into 2 (two), namely the outcome of a consumer dispute settlement by means of conciliation or mediation made in a written agreement signed by the consumer and the business actor. The written agreement is then strengthened by the decision of the BPSK assembly signed by the chairman and members of the assembly. The decision of the BPSK assembly does not contain administrative sanctions. Whereas the outcome of the consumer dispute settlement by way of arbitration is made in the form of an assembly decision and signed by the Chairperson and Members of the Assembly. The decision of this assembly can contain administrative sanctions.

\section{Consumer Dispute Settlement in Financial Service Sector through LAPS}

In the development of consumer dispute cases, there is also an Alternative Dispute Settlement Institution (LAPS) which is specifically aimed at consumers in the financial services sector with the characteristics of problems in the financial services sector. LAPS Financial Services Sector that has been formed and published in the List of Alternative Dispute Settlement Institutions by the Indonesian Financial Services Authority (OJK), comprising the Indonesian Insurance Arbitration and Arbitration Board (BMAI) for the Insurance Sector, the Indonesian Capital Market Arbitration Board (BAPMI) for the Capital Market, Pension Fund Mediation Board (BMDP) for the Pension Fund sector, Alternative Institution for Indonesian Banking Dispute Settlement (LAPSPI) for the

9 Based on Article 47, consumer dispute resolution outside the court is conducted to reach agreement in terms of the form and amount of compensation and/or certain actions to guarantee that there will be no recurrence of the losses suffered by the consumers. However, in practice, there are several disputes in which the BPSK decided to cancel the agreement that has been made between the consumer and the business actor, in this case, the author considers that BPSK has gone beyond its authority. This includes when receiving a dispute which incidentally the parties have agreed to resolve the dispute not through BPSK. 
Banking sector, Arbitration and Mediation Board for Indonesian Guarantee Company (BAMPPI) for the Guarantee sector, Indonesian Financing and Pawnshop Mediation Board (BMPPI) for the Financing sector and Procurement. ${ }^{10}$

OJK issued a Financial Services Authority Regulation (POJK) No. 1/ POJK.07/2014 on Alternative Dispute Settlement Institutions (LAPS) in the Financial Services Sector. Based on the POJK, if a customer complaint cannot be resolved by the Bank, then the customer can submit a dispute settlement through a court or alternative dispute settlement institution in the banking sector. Submission of dispute resolution through banking mediation is carried out by the customer in writing as the format stipulated by the Bank Indonesia.

To limit the scope of the research, the author focuses on LAPSPI as part of LAPS under OJK. Banking dispute settlement methods used by LAPSPI which are institutionally under the OJK include arbitration, mediation and adjudication. LAPSPI receives complaints from customers as consumers of financial services, but different from the end-consumers which are mandatory requirements for filing a lawsuit to BPSK, and the authority of BPSK, in this case, is wider i.e., to deal with disputes of consumers who are harmed both as consumers of goods and services.

Dispute resolution through this institution is confidential so that each disputing party is more comfortable in the dispute resolution process, and does not require a long time because it is designed to avoid procedural and administrative delays. The existence of the Alternative Dispute Settlement Institution (LAPS) for financial services sector has brought legal certainty to consumer dispute resolution in the financial services sector. However, the existence of the LAPS for financial services sector also created a lack of clarity regarding the position and choice of consumer dispute resolution forums related to the existence of the Consumer Dispute Settlement Agency (BPSK) in the legal framework for consumer protection in Indonesia. ${ }^{11}$

\footnotetext{
${ }^{10}$ Otoritas Jasa Keuangan, 'Edukasi Dan Perlindungan Konsumen’ (Otoritas Jasa Keuangan, 2016)<http://www.ojk.go.id/id/kanal/edukasi-dan-perlindungan-konsumen/Pages/LembagaAlternatif-Penyelesaian-Sengketa.aspx> accessed 9 April 2016.

${ }^{11}$ Agus Suwandono and Deviana Yuanitasari, 'The Position of Alternative Dispute Settlement of Finance Service in Consumer Protection Law’ (2015) 1 Bina Mulia Hukum.[14].
} 


\section{Commodity Futures Trading Arbitration Body (BAKTI)}

All civil cases regarding transactions in commodity futures trading can be resolved through BAKTI. The case can only be resolved at BAKTI if there is a request from the parties to the dispute, and the request is based on an arbitration agreement between the parties. The main purpose of the establishment of BAKTI is to provide alternative dispute resolution outside the court to all commodity futures traders in Indonesia to resolve civil disputes they in the capital market sector through a mechanism that is faster, easier, cheaper and with a final and binding settlement. BAKTI does not limit whether capital market players in Indonesia are domestic or foreign and whether the transactions are in Indonesia or abroad. The most important thing is the agreement between the disputing parties that the dispute will be resolved through BAKTI.

Based on the aforementioned description, it can be seen that each consumer dispute settlement institution has its own specialty, either in the form of applied methods, time limits for completion, and criteria for its customers. The table below summarizes the differences of the consumer dispute settlement institution outside the court.

Table I

Summary of Consumer Dispute Settlement Institution outside the Court

\begin{tabular}{|c|c|c|c|c|}
\hline & $\begin{array}{c}\text { Consumer Dispute } \\
\text { Settlement Institution }\end{array}$ & Types of Dispute & $\begin{array}{l}\text { Applied } \\
\text { Method }\end{array}$ & $\begin{array}{c}\text { Settlement } \\
\text { Duration }\end{array}$ \\
\hline 1 & BPSK & $\begin{array}{l}\text { Consumer disputes, usually } \\
\text { consumers goods/service }\end{array}$ & $\begin{array}{l}\text { - Mediation } \\
\text { - Conciliation } \\
\text { - Arbitration }\end{array}$ & $\begin{array}{l}\text { Maximum } \\
\text { of } 30 \text { Days }\end{array}$ \\
\hline 2 & LAPS (LAPSPI) & $\begin{array}{l}\text { Consumers of Financial } \\
\text { Services/Banking (Civil Case) }\end{array}$ & $\begin{array}{l}\text { - Mediation } \\
\text { - Conciliation } \\
\text { - Arbitration }\end{array}$ & $\begin{array}{l}\text { Maximum } \\
\text { of } 30 \text { Days }\end{array}$ \\
\hline 3 & BAKTI & $\begin{array}{l}\text { Consumers of commodity } \\
\text { futures trading }\end{array}$ & - Arbitration & $\begin{array}{l}\text { Maximum } \\
\text { of } 30 \text { Days }\end{array}$ \\
\hline
\end{tabular}

Source: The Author's Analysis, 2017.

Based on the provision that only a court decision that has an executive title with the verdict head of "In the name of Justice, by the Grace of God Almighty". Whereas the decisions made at BPSK, LAPSPI, and BAKTI do not have the force 
to carry out the contents of the decision. The decisions from the institution as well as mediation and arbitration decisions, in general, can be submitted back to the court by one of the parties to be examined from the beginning by refiling a claim or filing an objection.

Plurality in the field of consumer dispute resolution is related to existing institutions and regulations. Each agency has the authority to act based on rules made by agencies/Bodies. The existence of such plurality causes complication in dispute resolution as well as can create obstacles to the attainment of legal certainty in law enforcement efforts. To take a case in point, for consumers who are harmed in financial services traffic activities, there is no prohibition of selection to settle the dispute through BPSK rather than bringing a dispute to be resolved through LAPSPI. With the existence of pluralistic regulations, there are two or more different regulations in the same case, which causes legal uncertainty in applying the rules. This is in line with the opinion of Erman Rajagukguk that the condition of legal plurality in Indonesia causes many problems; the most challenging obstacle is in realizing legal certainty. ${ }^{12}$

\section{Consumer Dispute Settlement in Singapore}

Singapore and Indonesia are countries that are both located in Southeast Asia but have different legal systems. As part of the normative juridical description, the author uses comparative methods of law with Singapore. A legal comparison is a method of inquiry to discuss a legal issue in any field, including law. The method used is to compare one legal institution from a legal system with a more or less the same legal institution, from another legal system. The legal system is also influenced by cultural and political patterns of a country.

Mechanism and procedures for disputes resolution carried out through the courts are strongly influenced by the legal system adopted by a country. As an example, the main principle that forms the basis of the civil law system that the law

${ }^{12}$ Erman Rajagukguk, 'Plurality of Law in Indonesia', Kongres Internasional ke 15 tentang Pluralisme Hukum (Fakultas Hukum Universitas Indonesia 2006). 
has binding power because it is manifested in regulations in the form of laws and systematically arranged in certain codifications or compilations. This basic principle is adhered to considering the main value as a legal objective in this legal system is a legal certainty. Unlike the civil law, common law system, the legal system develops under the influence of an adversarial system that is based on a court decision based on tradition, customs, and precedent. ${ }^{13}$

Authority (jurisdiction) of each court in Singapore is determined by the value of the object of the lawsuit for civil cases, while the criminal case depends on the type of action committed and the length of the sentence. The judiciary in Singapore consists of subordinate court and supreme court. The subordinate courts which include small claims tribunal, coroners court, family and juvenile court, magistrate court, district court; and supreme court which consists of high court and court of appeal. Both the subordinate court and the supreme court both handle civil and criminal cases. In Singapore, in addition to being resolved through the courts, alternative institutions for the resolution of disputes are also developed, which among others are used to resolve consumer disputes such as the Insurance Dispute Resolution Organization (IDRO) which specializes in resolving insurance disputes, but not as growing as alternative institutions to resolve consumer disputes as occurred in Indonesia. In Singapore, the majority of consumer dispute resolution is settled through State Court in which there are Small Claims Tribunal (SCT) rooms and Consumer Association of Singapore (CASE) which are independent private institutions. ${ }^{14}$

Consumer Dispute Resolution Through CASE, Consumer Association of Singapore was established in 1971. It is a private association funded by non-profit members to provide various information through socialization of knowledge about consumer protection. Claims settled through CASE are claims submitted by endconsumers with a maximum claim value of $\mathrm{S} \$ 2,000$, either in the form of default claims or due to illegal laws. ${ }^{15}$

\footnotetext{
${ }^{13}$ Romli Atmasasmita, Comparison of Penal Law (Mandar Maju 2002).[35].

14 Anita Afriana (n 2).Op.Cit.[226].

15 ibid. [8].
} 
CASE has the authority to settle claims made by private individuals to sue for damages relating to goods and services, in this case, as end-consumers who use goods and services for their own benefit in Singapore, as well as claims made by tourist to travel agents in Singapore. CASE is not authorized to settle claims of consumers who sell goods and services for business purposes. ${ }^{16}$

Dispute resolution through CASE with a Small Claims Procedure (SCP) method is prompt and cost-efficient. The mechanism used by CASE to resolve claims is through negotiation, consolidation, and mediation. CASE is not an adjudication in relation to the rights obtained legally or obligations arising from the achievement of an agreement, meaning that an agreement is reached by the parties to the dispute. ${ }^{17}$ If the settlement conducted through CASE does not provide satisfactory results for the Complainant, CASE recommends that the claim is resolved through SCT. ${ }^{18}$ CASE does not have the authority to force the losing party to implement the agreement as SCT can do. In the event that CASE succeeds in mediating the parties, but the party who loses breaks the promise of the agreement that has been made, then CASE does not have a further mechanism that can be used to force and convince that compensation will be given in accordance with the agreement of the parties. ${ }^{19}$

\section{Dispute Settlement through Small Claims Tribunal (SCT)}

The Small Claims Tribunal in Singapore was established on 1 February 1985 under the Small Claims Tribunals Act, ${ }^{20}$ which was created with the aim of providing a fast, efficient, and inexpensive service to resolve disputes arising from small claims. ${ }^{21}$ A lawsuit can be filed by an individual, company, business person, part of a partnership, department of a government, state institution, public policy makers, and

\footnotetext{
${ }^{16}$ ibid.

17 ibid.

${ }^{18}$ An Interview with Juliana Ho, Assistant Director of Consumer Relations, Consumer Association of Singapore [9/12/2015].

19 ibid.

20 Statutes of The Republic of Singapore (the Act), 1998 Revised Edition, Chapter 308

${ }^{21}$ Statecourts Singapore, 'Small Claims' (Statecourts Singapore, 2016) < https://www.statecourts.gov.sg/Smallclaims/Pages/GeneralInformation.aspx. > accessed 2 June 2016.
} 
consumer. The parties must be domiciled in Singapore. This is for the effectiveness of binding and prompt litigation processes, namely consultations conducted in 7 (seven) days for consumers and 10-14 days for claims from companies counted as filing a lawsuit, as well as conducting hearings within 7 (seven) days from the last day of consultation if an agreement has not been achieved. ${ }^{22}$

There are 2 methods used in the SCT, namely mediation and adjudication with an assistance of judges who are usually called referees. ${ }^{23}$ The main function of the SCT is to position the disputing parties to agree and to resolve the problem, even though in the end, it is the clerk or referee who will assist the parties in the settlement process. If it is not possible to approve the agreement in a timely manner/ under the time that has been determined, the tribunal will determine the settlement by considering the goodness and fairness for both parties, whether the agreement is reached by the parties themselves or determined by the SCT, the tribunal will make binding decisions and can be imposed on the parties in dispute. ${ }^{24}$

Settlement through the tribunal is conducted in an informal way. When a claim is registered, the clerk will call the parties to the tribunal to discuss a suitable way to resolve the dispute. The Registrar, in this case, is referred to as a consultant. If the clerk does not succeed in facilitating the parties to reach an agreement, the clerk will determine the right date so that the claim can be settled through adjudication by the referee. Adjudicators acting as judges during hearings in the tribunal are called referees.

The ambience of the consultations and hearings are informal and closed. Unlike in courts, clerks and referees may not sit higher than the parties. The Tribunal does not rigidly follow the procedures in the court and it has its own policy to assess evidence, such as witnesses without swearing and written evidence without being legalized.

\footnotetext{
${ }^{22}$ Anne Durray, 'The Small Claims Tribunal Subordinate Court Republic of Singapore: Some Throughts on Current Issues of National Justice and Tribunals', the 5th Annual AIJA Tribunals Conference (2002).[37].

${ }^{23}$ Section 12 (1) of The Small Claims Tribunals Act, cap 308, The Statutes of The Republic of Singapore, Revised Edition, 1985.

24 Billy Low and Jessica Ng, Making Small Claims Do It Yourself (Longman Singapore Publishers ( Pte) Ltd 1994).[13].
} 
A lawsuit can be filed either personally, by fax, ${ }^{25}$ or by electronic means (for certain authorized users). ${ }^{26}$ Subsequent to submission, this issue will be resolved by consultation with a time span of 10 to 14 days from the date of filing a lawsuit from the company, and 7 (seven) days for a lawsuit from the consumer. The following table illustrates the costs needed to register a claim:

Table II

The Cost to Register a Claim SCT Singapore

List of Cost to Register a Claim SCT

\begin{tabular}{llll} 
Value of Claim & $\begin{array}{l}\mathrm{S} \$ 5,000 \\
\text { or less }\end{array}$ & $\begin{array}{l}\text { More than } \\
\mathrm{S} \$ 5,000 \text { but less than } \\
\mathrm{S} \$ 10,000\end{array}$ & $\begin{array}{l}\text { More than } \$ \$ 10,000 \text { but less } \\
\text { than } \$ \$ 20,000\end{array}$ \\
Consumer & $\$ 10.00$ & $\$ 20.00$ & $1 \%$ of the claim \\
Non-Consumer & $\$ 50.00$ & $\$ 100.00$ & $3 \%$ of the claim \\
\hline
\end{tabular}

Source: http www.statecourts.gov.sg/smallclaimstribunal.info

The method used in SCT is negotiation and mediation carried out continuously. If no settlement is reached with consultation, then the mediation will be carried out by the clerk or assistant court clerk. Mediation is mandatory for all claims filed. ${ }^{27}$ Mediation is conducted privately and informally. Parties are not permitted to delegate lawyers to represent them. If parties can come, the clerk or assistant clerk will check the consent order. If one of the parties is not present, the clerk or assistant clerk can consider or even reject the claim. The clerk or assistant clerk also has the rights to refuse a claim if it is filed outside the jurisdiction of the Tribunal.

If the parties do not reach an agreement in the consultation, the lawsuit continues at the hearing stage prior to being brought to the judge (referee). During the hearing, the judge will first try to assist the parties to reach an agreement. If an agreement is reached, the judge will record the consent order which reflects the agreement in the form of the wishes of the parties. If no agreement is reached, the judge will then adjudicate the claim. In the final stage, the judge will make a decision, but the judge at this stage may or may not reject the claim due to the absence of one of the

${ }^{25}$ Rule 11 G, Small Claims Tribunals Rules (1998) Edition of the Subsidiary Legislation of the Republic of Singapore ["the Rules"].

${ }^{26}$ Rule $11 \mathrm{~A}$ to $11 \mathrm{~F}$ of the Rules.

27 Section 17 of the Act. 
parties, and to stop the claim if it is outside the SCT jurisdiction. ${ }^{28}$ If the decision is not implemented voluntarily by the losing party, then the tribunal's decision can be implemented or forced through the subordinate court as ordered by the judge. ${ }^{29}$

If one of the parties is not satisfied with the court's decision, he/she can submit an appeal to the High Court. The reason for the appeal is limited to the issue of legal considerations and jurisdiction. During hearings at the appeal level, the high court can reject the appeal or ask the tribunal to conduct a re-hearing. ${ }^{30}$ Based on the aforementioned description, it appears that the resolution of consumer disputes in Singapore does not overlap between the authority of one institution and another. Consumer disputes in Singapore are classified as simple disputes with small losses that can be classified as small claims disputes.

With the background of a country that totally upholds the Common Law legal system, it is known as an adversary system in the judicial process. In this system, the disputing parties use lawyers when dealing with each other in court. Judges as referees who lead and process the proceedings may ask for jury consideration to declare win or lose, right or wrong. The jury statement is a decision that must be accepted by the judge, regardless of whether he/she agrees or not.

Consumer dispute resolution in the Singapore courts is conducted in a closed manner to maintain confidentiality and in an informal environment, which is the opposite of what happened in Indonesia. This is partly influenced by different legal systems between Indonesia and Singapore. When compared, judges in Indonesia are bound to the principle of civil procedural law when examining and deciding cases including that the trial must be conducted openly to the public except for certain disputes. Hence, it can be concluded that the pattern of law enforcement through the courts is strongly influenced by the legal system. Erman Rajagukguk, who stated that legal globalization would cause developing country regulations on investment, trade, and services in the economic field to converge the ones of the developed countries

\footnotetext{
${ }^{28}$ Section 29 of the Act

${ }^{29}$ Section 36 (1) of the Act

${ }^{30}$ Section 39 (1) of the Act
} 
(convergence), ${ }^{31}$ therefore, nowadays, it is not only in the field of economic law but also procedural law that there is a strong influence from the common law legal system.

Citing Sunaryati Hartono's statement, legal comparisons are used to compare institutions from countries that actually have different legal systems. ${ }^{32}$ The comparative function of law in the future era of legal development can be distinguished based on its function in the context of the growth of Indonesian law on one side and its function for legal practice and development on the other side, namely:

a. Legal Comparative Function for Indonesian Legal Development;

b. Legal Comparative Function for Legal Practices and Coaching.

From the function of legal comparison mentioned above, this method is also needed in the context of legal reform. Considering the occurrence of plurality in the settlement of consumer disputes, which ultimately lead to complication of procedures and institutions, thus, this is the time for legal and institutional harmonization in the matter of resolving consumer disputes in Indonesia.

\section{Conclusion}

Consumer dispute resolution in Indonesia is pluralistic because, in addition to being resolved through the courts, there are various alternative consumer settlement institutions. Based on the results of the analysis of the occurrence of this pluralism, it led to overlapping of authority and the complication of dispute resolution procedures.

By means of legal comparison, it can be concluded that in Singapore, the consumer disputes can be resolved through court and outside the court. However, the consumer dispute settlement through court is directed by the small claims procedure mechanism in the State Court with Small Claims Tribunal. This is different from the practices in Indonesia that do not specifically direct similar dispute (the one intended to be resolved through litigation) to be resolved with the small claims

${ }^{31}$ Erman Rajagukguk, 'The Role of Law in National Development in Globalization Era' (2003) II Jurnal Hukum Bisnis.[114].

${ }^{32}$ Sunaryati Hartono, A Compilation of Selected Readings on Comparative Law (Citra Aditya Bhakti 1991).[27]. 
court mechanism. Moreover, consumer disputes in Singapore are also resolved through CASE which only has the authority to resolve consumer disputes. Through legal comparison, the way consumer disputes are resolved more effectively and efficiently in Singapore can be used as a justification for Indonesia to be able to organize institutions and arrangements in order to achieve harmonization in the settlement of consumer disputes in Indonesia.

\section{Bibliography}

Agus Suwandono and Deviana Yuanitasari, 'The Position of Alternative Dispute Settlement of Finance Service in Consumer Protection Law' (2015) 1 Bina Mulia Hukum.

Anita Afriana, 'Business Dispute Settlement through Court with APrompt Mechanism and Legal Certainty (Small Claims Court) In the Framework of Reforming the National Civil Procedure Law' (Padjadjaran University 2017)

Anita Afriana dan Isis Ikhwansayah, 'Questioning The Small Claims Court in Indonesia In The Framework of National Civil Procedural Law Reform’ (2016) 16 Jurnal Dinamika Hukum.

Anne Durray, 'The Small Claims Tribunal Subordinate Court Republic of Singapore: Some Throughts on Current Issues of National Justice and Tribunals', the 5th Annual AIJA Tribunals Conference (2002).

Az. Nasution, Consumer Protection Law, An Introduction, (Diadit Media 2011)

Billy Low and Jessica Ng, Making Small Claims Do It Yourself (Longman Singapore Publishers ( Pte) Ltd 1994).

Candra Irawan, 'Problems of the Implementation of the Decree of the Supreme Court of the Republic of Indonesia No. 1 of 2008 in Civil Dispute Settlement in Indonesia' (2015) 1 Jurnal Hukum Acara Perdata ADHAPER.

Erman Rajagukguk, 'Plurality of Law in Indonesia', Kongres Internasional ke 15 tentang Pluralisme Hukum (Fakultas Hukum Universitas Indonesia 2006).

_, 'The Role of Law in National Development in Globalization Era' (2003) II Jurnal Hukum Bisnis.

Financial Services Authority Regulation (POJK) No. 1/POJK.07/2014 on Alternative 
Dispute Settlement Institutions (LAPS) in the Financial Services Sector.

Law No. 8 of 1999 on Consumer Protection.

Law No 30 of 1999 on Arbitration and Alternative Dispute Resolution.

Law of the Republic of Indonesia Number 48 Year of 2009 Concerning Judicial Affairs.

Ngadino, 'The Role of Law in Economic Globalization' (2014) 1 Jurnal Pembaharuan Hukum.

Otoritas Jasa Keuangan, 'Edukasi Dan Perlindungan Konsumen' (Otoritas Jasa Keuangan, 2016) <http://www.ojk.go.id/id/kanal/edukasi-dan-perlindungankonsumen/Pages/Lembaga- Alternatif-Penyelesaian-Sengketa.aspx $>$ accessed 9 April 2016.

R. Benny Riyanto, 'Remodelling and Repositioning of Court's Mediation in Indonesia' (2016) 1 Diponegoro Law Review.

Romli Atmasasmita, Comparison of Penal Law (Mandar Maju 2002).

Sunaryati Hartono, A Compilation of Selected Readings on Comparative Law (Citra Aditya Bhakti 1991).

Susanti Adi Nugroho, Mediation as an Alterantif Dispute Resolution (Telaga Ilmu Indonesia 2009).

Statecourts Singapore, 'Small Claims' (Statecourts Singapore, 2016) $<$ https://www. statecourts.gov.sg/Smallclaims/Pages/GeneralInformation.aspx. $>$ accessed 2 June 2016.

Tata Wijayanta, 'Principle of Legal Certainty, Justice and Benefit in Relation to Commercial Court Decision of Bankruptcy’ (2014) 4 Dinamika Hukum.

HOW TO CITE: Anita Afriana and Efa Laela Fakhriah, 'Understanding the Plurality of Consumer Dispute Resolution in Indonesia: A Comparative Study With Singapore' (2019) 34 Yuridika. 